\title{
KEPUASAN KERJA TERGANTUNG DARI KINERJA MANAJERIAL DAN PARTISIPASI PENGANGGARAN (Studi Pada Koran Harian Pagi Radar Kediri)
}

\author{
Anita Sumelvia Dewi \\ Jurusan Manajemen Universitas Islam Kadiri (Uniska), email:anitasumelviadewiazka@gmail.com
}

\begin{abstract}
This study aims to analyze how the influence of budget participation variables on managerial performance and job satisfaction. This research development from research of Wasisto and Sholihin (2004), In this research, Data used is primary data with spread questioner to respondent. From the questionnaires collected respondents obtained from employee perceptions and newspaper journalists Radar Kediri including middle managers and managers on it.

During the study, of the 70 questionnaires distributed, the 58 questionnaires (78.6\%) returned, but only 44 questionnaires answered completely so that the sample of this study was 44 people. Analysis of this research with Moderating Regression Analysis (MRA). The results in this study indicate that budgetary participation reinforces managerial performance and job satisfaction when budgetary participation interacts with procedural justice as a moderating variable, therefore the influence will be stronger and more significant. So the researcher concludes that there is influence between budget participation on managerial performance. Managerial performance also has a significant effect on job satisfaction.
\end{abstract}

\section{Keywords: Job satisfaction, Managerial Performance and Budgetary participation}

Penelitian ini bertujuan untuk menganalisis bagaimana pengaruh variabel partisipasi anggaran terhadap kinerja manajerial dan kepuasan kerja. Pengembangan penelitian ini dari penelitian Wasisto dan Sholihin (2004), Dalam penelitian ini, Data yang digunakan adalah data primer dengan penyebaran kuesioner kepada responden. Dari kuesioner Radar Kediri termasuk manajer menengah dan manajer di atasnya. Selama penelitian, dari 70 kuesioner yang didistribusikan, 58 kuesioner $(78,6 \%)$ kembali, tetapi hanya 44 orang yang menjawab sepenuhnya sehingga sampel penelitian ini adalah 44 orang. Analisis penelitian ini dengan Moderating Regression Analysis (MRA). Hasil penelitian ini menunjukkan bahwa partisipasi anggaran dari kinerja manajerial dan kepuasan kerja ketika penganggaran partisipasi berinteraksi dengan keadilan prosedural sebagai variabel moderating, sehingga pengaruh akan lebih kuat dan lebih signifikan. Jadi peneliti menyimpulkan bahwa ada pengaruh antara partisipasi anggaran pada kinerja manajerial. Kinerja manajerial juga memiliki pengaruh yang signifikan terhadap kepuasan kerja.

Kata Kunci: Kepuasan kerja, Kinerja Manajerial dan Partisipasi anggaran 


\section{PENDAHULUAN}

Sebuah organisasi membutuhkan anggaran untuk menerjemahkan keseluruhan strategi kedalam rencana serta tujuan jangka pendek juga jangka panjang (Hansen serta Mowen, 1997:151). Fungsi dari anggaran tersebut selain sebagai alat untuk pengendalian juga sebagai alat untuk mengkoordinasikan,

mengkomunikasikan, Radartivasi serta mengevaluasi prestasi (Kennis, 1979 dalam Hariyanti serta Nasir, 2002).

$\begin{aligned} \text { Dirtina et } & \text { al. (1996) dalam } \\ \text { Ghozali serta } & \text { Marsudi }\end{aligned}$ menyatakan bahwa untuk tetap bertahan dalam lingkungan persaingan saat ini, pelaku bisnis harus mempu menciptakan kondisi bisnis fleksibel serta inovatif, serta pelaku bisnis harus mempertimbangkan faktor eksternal perusahaan semakin sulit diprediksi. Maka dengan asertaya teknologi informasi semakin maju, dapat memformulasikan sistem informasi untuk menghasilkan informai akurat, tepat waktu serta dalam jumlah mencukupi (Susilawati M, 1998). Manajer perlu menyusun anggaran dengan baik karena anggaran merupakan gambaran perencanaan seluruh aktivitas operasional perusahaan (Siegel serta Marconi, 1989 : 138).

Suatu organisasi tidak akan efektif bila anggaran tersebut tidak dapat mengakomodasi semua kepentingan departemen terkait dalam pelaksanaannya, untuk itu penganggaran partisipasi digunakan untuk menumbuhkan sense of belonging setiap pelaksana anggaran (Pranesti serta Roekhudin, 2001). Proses penyusunan anggaran juga merupakan kegiatan penting dalam melibatkan berbagai pihak baik manajemen tingkat atas (top level management) maupun manajemen tingkat bawah (lower level management) akan memainkan peran penting dalam mempersiapkan serta mengevaluasi berbagai alternatif dari penganggaran partisipasi. Variabel partisipasi diambil sebagai titik tolak untuk menjalankan hubungan antara variabel lain terkait. Seperti telah dijelaskan sebelumnya, bahwa terdapat tiga pendekatan digunakan dalam penyusunan anggaran yaitu top - down (pendekatan dari atas ke bawah), bottom - up (pendekatan dari bawah ke atas) serta pendekatan lain merupakan gabungan dari kedua pendekatan tersebut, yaitu pendekatan partisipasi (Anthony serta Govindarajan, 1995). Oleh karena itu, partisipasi dalam penyusunan anggaran dapat mempengaruhi kinerja.

Dalam beberapa penelitian telah dilakukan oleh Bass serta Leavitt (1963); Schuler serta Kim (1976); Brownell (1982b); Brownell serta McInnes (1986); serta Indriantoro menemukan bahwa ada hubungan positif serta signifikan antara partisipasi penyusunan anggaran dengan kinerja manajerial. Sementara hasil penelitian Milani (1975); Kenis (1979); serta Ryanto (1996) menunjukkan bahwa terdapat hubungan tidak signifikan diantara partisipasi penyusunan anggaran dengan kinerja manajerial, sesertagkan penelitian lain melaporkan bahwa hubungan kedua variabel tersebut bertolak belakang atau negatif (Sterdy, 1960; Bryan serta Locke, 1967 dalam Riyadi, 1999). Penelitian lain telah dilakukan, disimpulkan bahwa persepsi bawahan (subordinat) mengenai keadilan merupakan pemrediksi penting atas sikap serta perilaku, dimana ternyata terdapat pengauh positif antara partisipasi dalam penyusunan angaran degan kepuasan kerja (Milani, 1975; Kenis, 1979).

\section{RUMUSAN MASALAH}

Berkaca dari latar belakang di atas, maka rumusan masalah penelitian ini adalah:

1. Apakah ada pengaruh yang signifikan antara partisipasi penganggaran terhaadap kinerja 
manajerial pada harian pagi Radar Kediri?.

2. Apakah ada pengaruh yang signifikan antara kinerja manajerial terhadap kepuasan kerja pada harian pagi Radar Kediri?.

\section{TINJAUAN PUSTAKA \\ Definisi Anggaran}

Kenis (1979) menyatakan bahwa anggaran adalah alat koordinasi serta komunikasi antara pimpinan serta bawahan dalam organisasi. Anthony serta Govindarajan (1998:373) mendefinisikan anggaran sebagai sebuah rencana keuangan, biasanya mencakup periode satu tahun serta merupakan alatalat untuk perencanaan jangka pendek serta pengendalian dalam organisasi. Hansen and Mowen (1997) mendefinisikan anggaran sebagai suatu rencana kuantitatif dalam bentuk moneter maupun nonmoneter digunakan untuk menerjemahkan tujuan serta strategi perusahaan dalam satuan operasional.

Oleh karena itu, dapat ditarik kesimpulan bahwa anggaran merupakan rencana kuantitatif dalam bentuk moneter serta nonmoneter sebagai alat koordinasi, komunikasi, perencanaan serta pengendalian laba dalam jangka waktu tertentu. Mulyadi (1993:488) mendefinisikan Anggaran (budget) sebagai suatu rencana terinci dinyatakan secara formal dalam ukuran kuantitatif dalam satuan moneter serta satuan ukuran lain untuk menunjukkan perolehan serta penggunaan sumbersumber suatu organisasi dalam jangka waktu tertentu, biasanya dalam satu tahun.

\section{Fungsi Serta Dampak Anggaran}

Menurut Garrison (2000) dalam Anggraeni (2003), perusahaan tidak akan mencapai tingkat kesuksesan maksimal jika tidak menggunakan sistem penganggaran terkoordinasi.
Garrison (1997) menyatakan bahwa fungsi anggaran adalah pengendalian serta perencanaan. Perencanaan mencakup pengembangan tujuan untuk masa depan, sesertagkan pengendalian digunakan untuk menjamin bahwa seluruh fungsi manajemen dilaksanakan sesuai dengan perencanaan telah ditetapkan sebelumnya (Garrison, 1997). Selanjutnya Siegel serta Marconi (1989:125) menyatakan bahwa anggaran juga berfungsi sebagai alat komunikasi nternal menghubungkan departemen atau divisi dalam organisasi, dengan manajemen puncak, mempengaruhi serta Radartivasi manajer untuk bertindak secara efektif, efisien. Anggaran juga berfungsi sebagai alat untuk Radartivasi kinerja para anggota organisasi (Chow et al., 1988), alat koordinasi (kenis, 1992), serta alat untuk mendelegasikan wewenang pimpinan kepada bawahan (Hofstede, 1968 dalam Supomo serta Indriantoro, 1998).

Selain dampak fungsional, anggaran dapat menimbulkan dampak disfungsional terhadap perilaku serta sikap anggota organisasi (Milani, 1975). Anggaran terlalu menekan akan menyebabkan ketegangan sehingga dapat menyebabkan inefisiensi (Argyris, 1952 dalam Supomo serta Indriantoro, 1998).

\section{Partisipasi Anggaran}

Partisipasi merupakan suatu konsep dimana bawahan ikut terlibat dalam pengambilan keputusan sampai tingkat tertentu bersama atasannya (Robbins, 2003). Polimeni et al., (1991) menyatakan bahwa penganggaran partisipasi merupakan suatu anggaran mengizinkan manajer tingkat menengah, bawah untuk merencanakan aktivitas mereka percaya secara realistis mampu dicapai, sesertagkan Heitger et al., (1992) menyatakan bahwa penganggaran partisipasi merupakan suatu proses menyiapkan anggaran 
menggunakan input dari manajer memegang tanggung jawab untuk performa anggaran.

Brownell (1982a) dalam Supomo serta Indriantoro (1998) menyatakan bahwa partisipasi dalam penyusunan anggaran merupakan proses dimana individu terlibat dalam penyusunan target anggaran, lalu individu tersebut dievaluasi kinerjanya, memperoleh penghargaan berdasarkan target anggaran. Faktor utama membedakan penganggaran patisipatif, non patisipatif adalah tingkat keterlibatan serta pengaruh bawahan dalam menyusun anggaran (Milani, 1975).

Inti dari penganggaran partisipasi adalah diperlukan kerjasama antara seluruh tingkatan organisasi. Manajer puncak biasanya kurang mengetahui bagian sehari-hari, sehingga harus mengandalkan informasi anggaran lebih rinci dari bawahannya. Sisi lain, manajer puncak mempunyai perspektif lebih luas atas perusahaan secara keseluruhan sangat vital dalam pembuatan anggaran secara umum. Setiap tingkatan tanggung jawab dalam suatu organisasi harus memberikan masukan terbaik sesuai dengan bisertagnya dalam suatu sistem kerjasama penyusunan anggaran (Garrison serta Noreen, 2000:409).

\section{Keunggulan Partisipasi Anggaran} Dunk (1990) serta Nur Indriantoro (1993) dalam Poerwati (2002) berpendapat bahwa kinerja dinyatakan efektif apabila tujuan anggaran tercapai serta bawahan mendapat kesempatan terlibat serta berpartisipasi dalam proses penyusunan anggaran serta Radartivasi bawahan mengidentifikasi serta melakukan negoisasi dengan atasan mengenai target anggran, menerima kesepakatan anggaran serta melaksanakannya sehingga dapat menghindarkan dampak negatif anggaran yaitu faktor kriteria kinerja, sistem pengahargaan (reward) serta konflik.

Siegel serta Marconi (1989:139) menyatakan bahwa keuntungan dari partisipasi adalah memacu peningkatan moral, serta inisiatif bagi mereka untuk mengembangkan ide serta informasi pada seluruh tingkat manajemen, meningkatkan group cohesiveness kemudian meningkatkan kerjasama antar individu dalam pencapaian tujuan, terbentuknya group internalization yaitu penyatuan tujuan individu serta organisasi, menghindari tekanan, kebingungan dalam melaksanakan pekerjaan serta manajer menjadi tanggap terhadap masalah-masalah sub unit tertentu, memiliki pemahaman lebih baik tentang

ketergantungan antar departemen.

\section{Kelemahan Partisipasi Anggaran}

Hansen serta Mowen (1997)

menyatakan bahwa penganggaran partisipasi dapat menyebabkan pembuatan standar terlalu tinggi sejak tujuan dianggarkan menjadi tujuan manajer. Sementara Dunk (1993) serta Yuwono (1999) menyatakan penganggaran partisipasi dapat menyebabkan senjangan anggaran, yaitu perbedaan antara jumlah sumber daya sebenarnya diperlukan untuk menyelesaikan tugas secara efisien dengan jumlah diajukan oleh manajer bersangkutan untuk mengerjakan tugas sama.

Menurut Hansen serta Mowen (1997:295) ada 3 masalah timbul menjadi kelemahan dalam partisipasi penganggaran antara lain :

1. Pembuatan standar terlalu tinggi atau rendah, sejak dianggarkan menjadi tujuan manajer.

2. Slack anggaran, adalah perbedaan antara jumlah sumberdaya sebenarnya diperlukan untuk menyelesaikan tugas secara efisien dengan jumlah diajukan oleh 
manajer bersangkutan untuk mengerjakan tugas sama.

3. Pseudoparticipation, mempunyai arti bahwa perusahaan menggunakan partisipasi dalam partisipasi penganggaran padahal sebenarnya tidak. Dalam

\section{Kinerja Manajerial}

Kinerja merupakan faktor penting digunakan untuk mengukur efektifitas serta efisiensi organisasi. Dalam penelitian ini, definisi kinerja digunakan mengacu pada penelitian Mahoney et al., (1963) dalam Supomo serta Indriantoro (1998). kinerja manajerial didasarkan pada fungsi fungsi manajemen ada dalam kinerja manajemen klasik yaitu: perencanaan, koordinasi, evaluasi, pengaturan staffi, negosiasi, investigasi, perwakilan serta pengawasan.

\section{Kepuasan Kerja}

Kepuasan kerja dapat didefinisikan sebagai keadaan emosi positif atau menyenangkan diakibatkan oleh penghargaan atas pekerjaan seseorang atau pengalaman pekerjaannya (Locke, 1976). Lind serta Tyler (1988) dalam Wasisto serta Sholihin (2004) menyimpulkan dalam penelitiannya bahwa prinsip keadilan tinggi dalam suatu perusahaan akan mendukung kepuasan kerja lebih tinggi. Dalam penganggaran, faktor manusia merupakan bagian penting. Siegel serta Marconi (1989) menyatakan bahwa manusia berada di balik aspek teknis dalam anggaran. Ia menetapkan tujuan serta bertanggungjawab pula untuk melaksanakan tujuan tersebut. Supomo serta Indriantoro (1998) menyatakan bahwa aspek human relation adalah hal penting dalam upaya peningkatan kinerja.

Kepuasan kerja adalah salah satu dampak dari aspek human relation tersebut. Hal ini dapat dilihat dari definisi kepuasan kerja, yaitu: Kepuasan kerja merupakan suatu sikap positif menkut penyesuaian diri sehat dari para karyawan terhadap kondisi serta situasi kerja, termasuk didalamnya masalah upah, kondisi sosial, kondisi fisik serta kondisi psikologis (Anoraga, 1998: 82) Kepuasan kerja merujuk pada sikap seseorang individu terhadap pekerjaannya, seseorang dengan tingkat kepuasan kerja tinggi menunjukkan sikap positif terhadap kerja itu (Robbins, 2003: 91) Definisi kepuasan kerja digunakan dalam penelitian ini mengacu pada teori Herzberg.

Herzberg et al., (1959) dalam Gibson et al., (1994) menggunakan pendekatan Incident Critical untuk mengukur kepuasan kerja. Pendekatan tersebut adalah analisis kepuasan dalam menentukan aspek terkait pada perilaku positif serta negatif. Perilaku pekerja adalah faktor penting harus diperhatikan, karena dapat mempengaruhi perilaku organisasi. Kepuasan kerja merupakan perilaku pekerja terhadap kerja mereka lakukan. Hal ini diwujudkan dalam tanggapan emosional pekerja pada situasi kerja merupakan hasil persepsinya (Luthan, 1992).

\section{Hubungan Partisipasi Anggaran - kinerja Manajerial}

Pengaruh penganggaran partisipasi pada kinerja manajerial merupakan tema menarik dalam penelitian akuntansi manajemen (Lukka, 1988) dalam (Supomo serta Indriantoro, 1998). Brownell (1982b) menyatakan alasan menariknya tema tersebut, yaitu: (1) Umumnya partisipasi dinilai dapat meningkatkan kinerja manjerial, (2) Hasil penelitian mengenai partisipasi dalam penyusunan anggaran terhadap kinerja menunjukkkan hasil tidak konsisten.

Salah satu fungsi dari partisipasi penganggaran adalah sebagai sarana komunikasi antara bawahan serta atasan, bawahan untuk mengemukakan 
kritiknya, untuk mencari informasi bagi penyelesaian tugas (Brownell serta Hirst, 1986), serta menjamin kecukupan anggaran (Nouri serta Parker, 1998) dengan mengikutsertakan input mereka pada sumber daya diperluklan untuk menyelesaikan tugas mereka.

$$
\text { Brownell (1982b) dalam }
$$

Supomo serta Indriantoro (1998) melakukan studi lapangan terhadap 48 manajer pusat biaya level menengah bekerja pada perusahaan-perusahaan menufaktur skala besar di San Fransisco. Penelitian ini menggunakan instrumen Milani (1975) untuk mengukur partisipasi penganggaran serta instrumen Mahoney et al. (1963) untuk mengukur kinerja manajerial tersebut, menemukan hubungan positif serta signifikan antara partisipasi dengan kinerja manajerial. Indriantoro (1993) dalam Supomo serta Indriantoro (1998) melakukan studi lapangan pada perusahaan pada berbagai ukuran serta tipe industri berlokasi di Jakarta. Berdasarkan jawaban 179 manajer dari berbagi fungsi antara lain akuntansi, administrasi, produksi, sistem informasi serta pemasaran, penelitian tersebut menemukan bahwa partisipasi dalam penyusunan anggaran akan meningkatkan kinerja manajerial.

\section{Hubungan Antara Partisipasi Penganggaran, Keadilan Prosedural - kinerja Manajerial \\ Dalam penelitiannya, Tang serta}

Starfield - Baldwin (1996) mengemukakan bahwa apabila manajer dapat menerapkan peraturan secara adil serta konsisten ke seluruh karyawan serta memberikan reward bagi mereka berdasarkan kinerja serta kelebihannya tanpa bias pribadi, maka karyawan akan memiliki persepsi positif mengenai keadilan prosedural, secara langsung dapat meningkatkan kepuasan, komitmen, serta keterlibatan (misalnya dalam penyusunan anggaran). Akan tetapi, Lind serta Tyler (1988) dalam Wasisto serta Sholihin (2004) mengungkapkan bahwa hubungan antara kinerja dengan variabel sikap (attitudinal variable) tidaklah bersifat langsung.

Lawler (1973) dalam Marsudi serta Ghozali (2001) menyatakan bahwa proses partisipasi memberikan kesempatan bagi bawahan untuk mengajukan pertanyaan kepada atasan. Dengan mengajukan pertanyaan maupun minta penjelasan, bawahan dapat memperoleh pemahaman lebih baik tentang tugas serta penyelesaiannya. Penerimaan pengetahuan berhubungan dengan tugas (task relevant knowledge) dapat meningkatkan kinerja. Persepsi bawahan mengenai seluruh proses diterapkan oleh atasan mereka untuk mengevaluasi kinerja mereka, sebagai sarana untuk mengkomunikasikan feedback kinerja serta menentukan reward bagi mereka seperti promosi atau kenaikan gaji (McFarlin serta Sweeny, 1992) akan secara langsung dapat meningkatkan penerapan keadilan prosedural dalam organisasi/perusahaan.

\section{Hubungan Partisipasi Anggaran Kepuasan Kerja}

Garrison serta Noreen (2000)

dalam Anggraeni (2003) menyatakan bahwa keunggulan partisipasi adalah menghargai pendapat serta pansertagan tingkat menengah serta bawah sehingga mereka lebih cenderung terdorong untuk mencapai anggaran. Selain itu, dalam penganggaran partisipasi terdapat sistem kendali unik, yaitu kesalahan serta tanggung jawab terdapat pada penyusun anggaran itu sendiri sehingga mereka tidak dapat berdalih bahwa anggarannya tidak masuk akal untuk dicapai. Dengan demikian dapat disimpulkan bahwa penganggaran partisipasi akan berpengaruh positif serta signifikan dalam meningkatkan kepuasan kerja.

Kepuasan kerja tergantung dari tingkat perolehan ekstrinsik (faktor hygiene) serta intrinsik (factor motivator) (Gibson et al., 1994). Oleh karena itu, penelitian 
ini menggunakan definisi kepuasan kerja (faktor ekstrinsik) mengacu pada teori Herzberg. Syptak et al., (1999) menyatakan bahwa berdasarkan teori tersebut, kepuasan kerja memiliki dua dimensi yaitu faktor hygiene serta faktor motivator: Syptak et al., (1999) menyatakan bahwa untuk mengurangi ketidakpuasan, mutu dari supervisor harus baik dalam menentukan anggaran.

Keputusan untuk menentukan seorang supervisor adalah hal sulit. Pekerja baik belum tentu dapat menjadi supervisor baik. Oleh karena itu, kepemimpinan serta kemampuan untuk memperlakukan pekerja dengan adil merupakan hal - hal harus dipertimbangkan dalam menentukan supervisor. Partisipasi dalam penyusnan anggaran mempunyai pengaruh signifikan pada hubungan antara penekanan anggaran serta kepuasan kerja.

\section{HIPOTESIS}

Berkaca dari latar belakang di atas, maka rumusan masalah penelitian ini adalah:

1. Diduga ada pengaruh yang signifikan antara partisipasi penganggaran terhaadap kinerja manajerial pada harian pagi Radar Kediri.

2. Diduga ada pengaruh yang signifikan antara kinerja manajerial terhadap kepuasan kerja pada harian pagi Radar Kediri.

\section{METODE PENELITIAN Jenis Penelitian}

$\begin{array}{lr}\text { Dalam suatu penelitian, } \\ \text { pemilihan jenis penelitian } & \text { akan } \\ \text { dilakukan merupakan hal sangat } \\ \text { penting untuk mempermudah } & \text { proses } \\ \text { penyelesaian penelitian itu } & \text { sendiri. } \\ \text { Dalam penelitian ini, peneliti } & \text { pen } \\ \text { menggunakan jenis penelitian } & \text { survey } \\ \text { dimana informasi dikumpulkan dengan } \\ \text { menggunakan kuesioner. Penelitian }\end{array}$

survey adalah suatu penelitian dilakukan untuk memperoleh fakta fakta dari gejala - gejala ada serta untuk mencari keterangan - keterangan secara faktual, baik tentang institusi sosial, ekonomi/politik dari suatu kelompok atau suatu daerah (Hasan, 2002). Umumnya survey dibatasi pada survey sampel

dimana informasi dikumpulkan dari sebagian populasi untuk mewakili seluruh populasi serta lingkungan penelitian ini berada pada lingkungan sebenarnya/lapangan (Singarimbun, 1995).

\section{Sumber Data serta Jenis Data}

Sumber data penelitian adalah faktor penting digunakan untuk menentukan metode pengumpulan data. Sumber data dalam penelitian ini adalah sumber data primer. Data primer adalah sumber data penelitian diperoleh secara langsung dari sumber asli serta secara khusus dikumpulkan oleh peneliti untuk menjawab pertanyaan untuk penelitian (Indriantoro serta Supomo, 1999; 146). Data ini dapat berupa individual atau kelompok, hasil observasi, serta hasil pengujian.

\section{Jenis Data}

Jenis data penelitian berkaitan dengan sumber data serta pemilihan metode untuk memperoleh data penelitian. Jenis data dalam penelitian ini adalah data subjek (self-report data) yaitu data penelitian berupa opini, sikap, pengalaman, atau karakteristik dari seseorang/sekelompok orang menjadi subjek penelitian (Indriantoro serta Supomo, 1999; 145). Data subjek ini juga dapat berasal dari berbagai bentuk tanggapan atau respon diberikan, yaitu lisan, tulisan, serta ekspresi.

\section{Unit Analisis}

Unit analisis merupakan tingkat agregasi data dianalisa dalam penelitian. Unit 
analisis ini merupakan elemen penting dalam desain penelitian, karena mempengaruhi proses pemilihan, penyampelan, serta analisis data. Unit analisis digunakan dalam penelitian ini adalah tingkat individu, karena diamati adalah perilaku manajer berkaitan dengan gaya pengambilan keputusan mereka (Indriantoro serta Supomo, 1999; 94).

\section{Populasi Serta Sampel}

Populasi dari penelitian ini adalah seluruh karyawan dan wartawan koran Radar Kediri termasuk manajer menengah dan manajer di atasnya jumlahnya 70 orang. Dalam penelitian ini penulis membagikan kuesioner dan didapat kuesioner kembali adalah 58 kuesioner $(78,6 \%)$, tetapi hanya 44 kuesioner menjawab secara lengkap sehingga sampel penelitian ini adalah 44 orang.

\section{Metode Analisis Data}

Dalam

rangka

menganalisis data (agar sesuai dengan tujuan penelitian ini), maka data dianalisis secara kuantitatif untuk menjelaskan profil Radar dilihat dari umur perusahaan, modal usaha, tenaga kerja, biaya produksi, san volume kepuaasan kerja.

Disamping itu, juga dilakukan analisis kuantitatif. Secara kuantitatif artinya memakai uji statistik menjawab hipotesis dikemukakan dengan regresi linear berganda. Model regresi linear berganda digunakan untuk mengetahui sejauh mana pengaruh antara variabe-variabel bebas terhadap variabel terikat baik secara parsial maupun secara serempak. Perhitungan statistik didasari hasil angket pembaca harian pagi Radar Kediri, berjumlah 50 responden (Sesuai ketentuan, jumlah responden minimal 5 kali variabel diteliti). Hal ini sesuai pendapat Hamdy (1982) \&
Subagyo (1985) dalam bukunya menjelaskan pemberian skor pada analisa kwalitatif menjadi kwantitatif dengan klasifikasi sebagai berikut :

Untuk jawaban bagus

sekali ; Diberi nilai ; $90 \%(9,0)$ Untuk jawaban bagus ;

diberi nilai $80 \%(8,0)$

Untuk nilai cukup;

diberi nilai $70 \%(7,0)$

Untuk nilai kurang ;

diberi nilai $50 \%(5,0)$

Untuk jawaban kurang

sekali; diberi nilai $30 \%(3,0)$

Untuk jawaban jelek ;

diberi nilai 0 .

Dari data diperoleh selanjutnya dianalisis dengan model regresi linear berganda, korelasi berganda serta korelasi parsial. Adapun bentuk implisitnya adalah sebagai berikut:

$$
\mathrm{Y}=\mathrm{f}(\mathrm{X} 1, \mathrm{X} 2)+\mathrm{E}
$$

Keterangan

$\mathrm{Y} \quad=$ Hasil kepuaasan kerja

$\mathrm{E}=$ Variabel pengganggu

$\mathrm{X}, \mathrm{X} 2=$ Faktor/variabel

keunggulan strategis

Berdasarkan variabel diturunkan dalam hipotesis maka secara spesifik, menggunakan model regresi linear berganda karena dilihat adalah pengaruh beberpa variabel bebas terhadap variabel tidak bebas. Formulasi tersebut secara eksplisit adalah sebagai berikut:

$\mathrm{Y}=\mathrm{bo}+\mathrm{b} 1 \mathrm{X} 1+\mathrm{b} 2 \mathrm{X} 2+\mathrm{e}$

Keterangan

$\mathrm{Y}=$ Variabel tidak bebas,yaitu hasil kepuaasan kerja Radar Kediri.

$\mathrm{Bo}=$ Bilangan Konstanta.

$\mathrm{X} 1, \mathrm{X} 2$ = Variabel bebas

$\mathrm{B} 1, \mathrm{~b} 2=$ Koefisien regresi masingmasing variabel bebas.

$\mathrm{E}=$ Error (variabel yg tidak dianalisis) 


\section{Pengujian Hipotesa}

Rumus digunakan menghitung R2 sebagai berikut :

$$
\mathrm{R} 2=\frac{\mathrm{JK}(\mathrm{Reg})}{\mathrm{Y} 2} \quad(\text { Sudjana; 1991) }
$$

Keterangan

$$
\begin{array}{ll}
\mathrm{R} 2 & =\text { Koefisien determinasi } \\
\mathrm{JK}(\mathrm{Reg}) & =\text { Jumlah kwadrat (Reg) } \\
\mathrm{Y} 2 & =\mathrm{JK} \text { (total dikoreksi) }
\end{array}
$$

Kegunaan R2 adalah mengukur ketepatan paling baik dari analisis regresi linier ganda. Jika R2 mendekati 1 (satu), maka dikatakan semakin kuat model ini menerangkan variasi variabel bebas terhadap variabel tidak bebasnya. Sebaliknya, bila R2 mendekati 0 (nol), maka semakin lemah variasi variabel bebas menerangkan variasi variabel tidak bebas. Secara umum dikatakan, besarnya sumbangan variabel bebas terhadap variabel bebas secara keseluruhan dapat dijelaskan dengan melihat besarnya nilai koefisien determinasi berganda (R2), berada antara 0 serta 1 atau secara matematis nol $<$ r2 $<1$.

\section{HASIL PENELITIAN SERTA PEMBAHASAN}

\section{Gambaran Umum Responden}

Dengan menggunakan metode pengumpulan data melalui kuesioner, terdapat 44 jawaban responden layak diuji serta diolah lebih lanjut. Gambaran umum responden diklasifikasikan menurut usia, jenis kelamin, pendidikan terakhir, jabatan, lama responden menjabat di posisinya sekarang serta lama bekerja di perusahaan serta jumlah bawahan.

Dari 70 kuesioner disebarkan, jumlah kuesioner kembali adalah 58 kuesioner $(78,6 \%)$ serta 14 diantaranya tidak terisi lengkap. Dengan demikian, ada 44 jawaban kuesioner digunakan untuk diolah dalam analisis data. Dari 44 kuesioner diolah serta disajikan pada tabel diatas, responden paling banyak berpartisipasi dalam penelitian ini berusia antara 20-30 tahun yaitu 21 orang $(47,7 \%)$. Responden berjenis kelamin pria paling banyak berpartisipasi dengan jumlah sekitar 28 orang $(63,6 \%)$, sesertagkan sisanya berjenis kelamin wanita. S1 merupakan pendidikan terakhir paling banyak dimiliki responden yaitu 20 orang (45,5 $\%$ ), kemudian D3 serta SLTA. Serta paling banyak menempati jabatan sebagai lower manajer yaitu 31 .

\section{Statistik Deskriptif}

Statisitik deskriptif merupakan proses transformasi data penelitian dalam bentuk tabulasi sehingga mudah dipahami serta diintrepretasikan. Statistik deskriptif digunakan untuk memberikan informasi mengenai karakteristik variabel penelitian utama serta data demografi responden. Pengukuran ini umumnya dibutuhkan karena mampu menggambarkan pemusatan nilai-nilai observasi sampel (Dajan, 1986:172). Pengukuran statistik sampel dalam penelitian ini dilakukan dengan menggunakan program komputer Statistical Package for Social Science (SPSS) versi 12.0.

\section{Perhitungan Statistik}

Perhitungan statistik ini didasari hasil angket berhubungan dengan variabel partisipasi penganggaran, kinerja manajerial serta kepuasan kerja. Adapun perhitungan ini memakai program statistik SPSS, dengan taraf significant $(\propto)=5 \%$. Untuk perhitungan regresi serta kolerasi, penulis berpedoman pada hasil survei (angket) sebanyak 44 orang. Dari data ada, diuraikan dalam perhitungan statistik program SPSS dengan hasil sebagai berikut: 
Perhitungan regresi Antara Variabel bebas terhadap Kepuaasan kerja

\begin{tabular}{|l|r|r|r|}
\hline & \multicolumn{1}{|c|}{$\mathrm{Y}$} & \multicolumn{1}{c|}{ X1 } & \multicolumn{1}{c|}{ X2 } \\
\hline Pearson & 1.000 & .620 & .348 \\
Y & .620 & 1.000 & .292 \\
Correlation & .348 & -.220 & -.085 \\
X1 & & & \\
X2 & & & \\
\hline Sig. & .000 & .000 & .007 \\
Y & .007 & .062 & .062 \\
(1-tailed) & & & \\
X1 & & & \\
X2 & 44 & 44 & 44 \\
\hline N & 44 & 44 & 44 \\
Y & 44 & 44 & 44 \\
X1 & & & \\
X2 & & & \\
\hline
\end{tabular}
(2018)

Hasil perhitungan korelasi diatas menunjukkan, antara variabel terikat serta 2 variabel bebas (X1, X2) ada hubungan sangat erat antara kedua variabel dengan hasil kepuasan kerja. Hal ini terlihat dari hasil regresi sebesar 0,62 untuk X1, 0,348 untuk X2, 0,6. Agar mampu memberikan gambaran lebih jelas analisis pengaruh 4 variabel pada kepuasan kerja Radar Kediri, dapat dilihat dari lanjutan tabel 6 dibawah ini. menggambarkan urutan pengaruh variabel $(\mathrm{X} 1, \mathrm{X} 2)$ paling besar hingga paling kecil terhadap omset kepuaasan kerja (Y).

\section{Urutan pengaruh variabel bebas terhadap (Y)}

\begin{tabular}{|l|l|}
\hline $\begin{array}{l}\text { VARIABE } \\
\text { L }\end{array}$ & $\begin{array}{l}\text { HASIL } \\
\text { PERHITUNGA } \\
\text { N STATISTIK }\end{array}$ \\
\hline $\mathrm{X} 1$ & 0,62 \\
\hline $\mathrm{X} 3$ & 0,60 \\
\hline
\end{tabular}

Sumber : Data primer diolah (2018)
Berdasarkan data dari tabel dibawah ini menunjukkan semua item pertanyaan untuk variabel Kepuasan Kerja mempunyai nilai korelasi lebih besar dari 0.5 serta mempunyai koefisien alpha 0.903 Dengan demikian berarti bahwa item pertanyaan untuk variabel Kepuasan Kerja (Y2) valid serta reliable untuk pengujian selanjutnya.

\section{Uji R antara Variabel bebas \&} Variabel Terikat

\begin{tabular}{|l|r|l|l|l|l|}
\hline \multicolumn{7}{|c|}{ Model Summary } \\
del & R & $\begin{array}{l}\text { R } \\
\text { Squ } \\
\text { are }\end{array}$ & $\begin{array}{l}\text { Adjus } \\
\text { ted R } \\
\text { Squar } \\
\text { e }\end{array}$ & $\begin{array}{l}\text { Std.Er } \\
\text { ror Of } \\
\text { the } \\
\text { estim } \\
\text { ate }\end{array}$ & $\begin{array}{l}\text { Durb } \\
\text { in - } \\
\text { Wats } \\
\text { on }\end{array}$ \\
\hline 1 & 1.0 & $\begin{array}{r}1.00 \\
00\end{array}$ & 1.000 & $\begin{array}{r}5.311 \\
\text { E-08 }\end{array}$ & .452 \\
\hline
\end{tabular}

a. Predictors: (Constant), X2, X1

b. Dependent Variable: $\mathrm{Y}$

Sumber : data primer diolah

Distribusi normal merupakan distribusi teoritis dari variabel random kontinyu (Dajan, 1986). Kurva menggambarkan distribusi normal adalah kurva normal berbentuk simetris. Untuk menguji apakah sampel penelitian merupakan jenis distribusi normal maka digunakan pengujian KolmogorovSmirnov Goodness of Fit Test terhadap masing-masing variabel. Berdasarkan tabel diatas, diketahui nilai $\mathrm{R}$ serta $\mathrm{R}$ square sebesar 1,00 lebih besar dari 0,05 , menunjukkan hipotesa $0(\mathrm{H} 0)$ ditolak serta hipotesa alternatif (H1) diterima.

Pembahasan Hasil Pengujian Hipotesis Dari hasil pengujian hipotesis dengan analisis regresi ditemukan bahwa partisipasi dalam penyusunan anggaran menguatkan kinerja manajerial (nilai t hitung lebih besar dari t tabel, yaitu $4.833>1.980$ ). Hal ini menunjukkan bahwa partisipasi tinggi dalam penyusunan anggaran akan meningkatkan kinerja manajerial. Hasil temuan tersebut sesuai dengan teori 
telah ditemukan sebelumnya. Melalui partisipasi, manajer dapat mengumpulkan informasi, pengetahuan, kekuatan, serta kreativitas untuk memecahkan persoalan dapat meningkatkan kinerja (Gibson et al., 1994 dalam Mirthasari, 2004).

Internalisasi tujuan organisasi oleh para manajer akan meningkatkan efektifitas organisasi, karena konflik potensial antara tujuan individu dengan tujuan oganisasi dapat dikurangi bahkan dapat dihilangkan. Greenberg serta Folger (1983) dalam Hariyanti serta Nasir (2002) berpendapat bahwa partisipasi dapat meningkatkan kinerja karena (i) partisipasi memungkinkan bawahan mengkomunikasikan apa mereka butuhkan kepada atasannya serta (ii) partisipasi dapat memungkinkan bawahan untuk memilih.

Tindakan memilih tersebut dapat membangun komitmen serta dianggap sebagai tanggung jawab atas apa telah dipilih. Semua kelebihan partisipasi ini sangat mungkin akan memperluas tingkat persetujuan dengan gaya evaluasi digunakan, sehingga pada akhirnya akan meningkatkan kinerja (Otley, 1978) dalam Yenti (2003). Hal ini menunjukkan hubungan positif antara partisipasi penganggaran dengan kinerja manajerial.

Hasil penelitian ini berhasil mengkonfirmasi penelitian sebelumnya yaitu Brownell (1981), Brownell (1982b), Brownell serta Mclnes (1986), Indriantoro (1992) dalam Marsudi serta Ghozali (2001), Hariyanti serta Nasir (2002), Puspaningsih (2002) berhasil membuktikan hubungan positif serta signifikan antara kinerja manajerial dengan partisipasi anggaran. Serta tidak konsisten dengan hasil penelitian Milani (1975), Kenis (1979), Brownell \& Hirst (1986), Riyadi (1999), Supomo serta Indriantoro (1998), Yenti (2003) menemukan hubungan tidak signifikan.

Hasil pengujian hipotesis kedua ini menggunakan metode Moderating
Regression Analysis (MRA) (Gozali, 2001; 92), dimana metode ini menghubungkan satu variabel independen dengan variabel dependen. Pengujian pada hipotesis kedua (H2) dalam penelitian ini, merupakan pengembangan dari penelitian telah dilakukan sebelumnya oleh Puspaningsih (2002) meneliti hubungan antara partisipasi anggaran terhadap kinerja manajerial serta kepuasan kerja, menemukan bahwa terdapat hubungan positif antara partisipasi anggaran terhadap kinerja manajerial serta kepuasan kerja.

Peneliti mencoba memperluas pembahasan dengan memasukkan variabel keadilan prosedural sebagai variabel moderating. Alasan peneliti adalah, bahwa keadilan prosedural tidak berpengaruh secara langsung terhadap kinerja. Lindquist (1995) serta Libby (1999) menemukan bahwa keadilan prosedural merupakan persepsi dari bawahan mengenai pansertagan bahwa perusahaan telah menerapkan prosedur serta proses ang adil, karena keadilan prosedural merupakan faktor ekstrinsik berasal dari dalam perusahaan serta bukan dari diri seorang bawahan. Dalam penelitian ini ditemukan bahwa keadilan prosedural menguatkan hubungan antara partisipasi penganggaran terhadap kinerja manajerial (nilai t hitung lebih besar dari $t$ tabel, yakni $4.277<1.980$ untuk $\mathrm{X} 1 * \mathrm{X} 2$ ) Hal ini menunjukkan bahwa tingginya keadilan prosedural akan menguatkan hubungan

antara partisipasi penganggaran dengan kinerja manajerial.

Partisipasi pengganggaran memungkinkan bawahan untuk bertukar serta mencari informasi dari atasan mereka, tentunya dapat mendukung terciptanya pemahaman lebih mendalam mengenai proses penentuan anggaran serta urusan keorganisasian lain. Selain itu, partisipasi penganggaran juga memungkinkan bawahan untuk mengemukakan kritiknya, untuk 
mencari informasi bagi penyelesaian tugas (Brownell serta Hirst, 1986). Partisipasi penganggaran juga berhubungan secara positif dengan kinerja manajerial (Wasisto serta Sholihin, 2004).

Hasil penelitian ini konsisten dengan teori menyatakan partisipasi dalam penyusunan anggaran akan meningkatkan kinerja manajer melalui efek positifnya yaitu dari suatu prosedur adil, telah termuat pada berbagai buku bacaan akuntansi manajemen seperti ditulis oleh Argyris (1952), Becker \& Green (1962), Welsch (1976), serta juga konsisten dengan penelitian dilakukan oleh Wasisto serta Sholihin (2004).

Hasil pengujian hipotesis dengan analisis regresi sederhana ditemukan bahwa partisipasi penganggaran berpengaruh terhadap kepuasan kerja ditunjukkan dengan nilai signifikansi lebih kecil dari $\alpha$ ditetapkan $(p<0,05)$, yaitu 0.000 atau nilai $\mathrm{t}$ hitung lebih besar dari $\mathrm{t}$ tabel $(5.905>1.980)$. Hal ini menunjukkan bahwa partisipasi tinggi dalam penyusunan anggaran akan meningkatkan kepuasan kerja. Hasil temuan tersebut sesuai dengan penelitian - penelitian telah dilakukan sebelumnya oleh Puspaningsih (2002). Kepuasan kerja tergantung dari tingkat perolehan ekstrinsik (factor hygiene) serta intrinsik (factor motivator) (Gibson et al., 1994).

Oleh karena itu, penelitian ini menggunakan definisi kepuasan kerja mengacu pada teori Herzberg. Syptak et al., (1999) menyatakan bahwa berdasarkan teori tersebut, kepuasan kerja memiliki dua dimensi yaitu faktor hygiene serta faktor motivator: Syptak et al., (1999) menyatakan bahwa untuk mengurangi ketidakpuasan, mutu dari supervisor harus baik dalam menentukan anggaran. Keputusan untuk menentukan seorang supervisor adalah hal sulit. Pekerja baik belum tentu dapat menjadi supervisor baik.
Oleh karena itu, kepemimpinan serta kemampuan untuk memperlakukan pekerja dengan adil merupakan hal - hal harus dipertimbangkan dalam menentukan supervisor. Hasil penelitian ini konsisten dengan (Dijk, 1999) berhasil membuktikan partisipasi dalam penyusunan anggaran mempunyai pengaruh signifikan pada hubungan antara penekanan anggaran serta kepuasan kerja.

Hasil pengujian hipotesis keempat juga menggunakan metode Moderating Regression Analysis (MRA) (Gozali, 2001; 92). Pengujian pada hipotesis kedua (H4) dalam penelitian ini, merupakan pengembangan dari penelitian telah dilakukan sebelumnya oleh Puspaningsih (2002) meneliti hubungan antara kinerja manajerial serta kepuasan kerja dengan partipasi penganggaran. Peneliti mencoba mengembangkan penelitian Puspaningsih (2002) dengan memasukkan satu variabel moderating yaitu keadilan prosedural.

Dalam penelitian ini ditemukan bahwa keadilan prosedural menguatkan hubungan antara partisipasi penganggaran terhadap kepuasan kerja (nilai signifikansi lebih kecil dari nilai $\alpha$ ditetapkan $(p<0,05)$, yakni sebesar 0.008 atau dengan kata lain nilai t hitung lebih besar dari t tabel, yakni $2.796<1.980$ untuk $\mathrm{X} 1 * \mathrm{X} 2$. Hal ini menunjukkan bahwa tingginya keadilan prosedural akan menguatkan hubungan antara partisipasi penganggaran dengan kepuasan kerja. Hasil temuan dalam penelitian ini konsisten dengan penelitian dilakukan oleh Rawls (1971), Thibaut serta walker (1975), Lissak serta Sheppard (1983), Heuer serta Penrod (1986) . 


\section{KESIMPULAN}

Penelitian ini menguji apakah partipasi penganggaran mempunyai dampak terhadap kinerja manajerial serta kepuasan kerja. Untuk menganalisis pengaruh tersebut digunakan Moderating Regression Analysis (MRA) (Gozali, 2001; 92). Metode ini menghubungkan satu variabel independen dengan variabel dependen. Berdasarkan hasil pengujian data dari hasil penelitian terhadap manajer terlibat dalam penyusunan anggaran termasuk manajer middle serta lower dari harian pagi radar kediri, dapat ditarik kesimpulan sebagai berikut :

1.. Penelitian ini berhasil membuktikan hipotesis kedua bahwa partisipasi dalam penyusunan penganggaran berpengaruh signifikan terhadap kinerja manajerial dengan nilai signifikansi $p$ lebih kecil dari $\alpha$ ditetapkan $(p<0,05)$, yakni sebesar 0.000. Dari hasil analisis diperoleh nilai $\mathrm{R} 2=0.542$ Angka ini menunjukkan bahwa kemampuan variabel partisipasi penganggaran (X1) dalam menjelaskan atau memberikan sebagian besar informasi dibutuhkan untuk memprediksi variabel kinerja manajerial (Y1), dapat dijelaskan oleh persamaan regresi sebesar 54,2 $\%$, sesertagkan sisanya, yaitu $45,8 \%$, dijelaskan oleh variabel lain di luar persamaan model.

2. Penelitian ini berhasil membuktikan hipotesis kedua bahwa kinerja manajerial akan mempengaruhi kepuasan kerja dengan nilai signifikansi $p$ lebih kecil dari $\alpha$ ditetapkan $(p<0,05)$, yaitu 0.000 . Hal ini menunjukkan bahwa manajer berpartisipasi dalam penyusunan anggaran maka semakin meningkatkan kepuasan kerja.

\section{DAFTAR PUSTAKA}

Anthony, R. W., serta V. Govindarajan. 1998. Management Control System. Boston: 9th Edition, Mc Graw Hill Co.

Bachtiar, arief. serta D.S. Susilowati. 1998. Analisis Hubungan antara Penganggaran Partisipatif, Motivasi, serta kinerja Manajerial di PT. Badak NGL. Co. Bontang Kalimanatan Timur. Jurnal Akuntansi serta auditing Indonesia (JAAI). Vol.2, No.1.

Becker, S., and D. Green. 1978. Budgeting and Employee Behavior. Journal of Business 35 (January) : 392-402.

Brownell, P. 1981. Participation in the Budgeting Process, Locus of Control and Organizational Effectiveness. The Accounting Review. Vol. LVI, No.4, Oktober: 844-860.

Chenhall, R.H, serta P. Brownell. 1988. The Effect of Participative Budgeting on Job Satisfaction and Performance Role Ambiguity as an Intervening Variable. Accounting, Organization and Society. Vol. $13: 225-233$.

Dajan, Anton. 1986. Pengantar Metode Statistik. Jakarta: LP3S

Dunk, Alan S. 1993. The Effect of Budget Emphasis and Information Asymetry on The Relation Beetween Budgetary Participation and Slack. The Accounting Review. Vol.68, No.2, April : 400-410 
Garrison, Ray H serta Erick W Noreen. 2000. Managerial Accounting. Terjemahan Totok Budisantoso. 2004. Boston: Irwin McGraw Hill.

Gaspersz, J. 2003. Analisis Hubungan antara Struktur Desentralisasi, Partisipasi Anggaran dengan Job Relevant Information, VOI Manager serta Pengaruhnya terhadap Job Related Outcome. Simposium Nasional akuntansi VI, Surabaya.

Ghozali, I. Serta A.S. Marsudi. 2001. Pengaruh Partisipasi Penganggaran, Job Relevant Information serta Volatilitas Lingkungan terhadap kinerja Manajerial pada Perusahaan Manufaktur di Indonesia. Jurnal akutansi serta auditing Indonesia (JAAI). Vol.5, No.5.

Gibson, James L., John M. I., James f., D. 1997. Organisasi serta Manajemen. Jakarta : Erlangga.

Govindarajan, V. 1986. Impact of Participation in the Budgetary Process on Attitudes and Performance. Universalistic and Contigency Perspectives. Decision Sciences halaman 496-516.

Hanson, Don R., serta Maryanne M. Mowen. 1997. Managemen Accounting. $7^{\text {th }}$ Edition. USA: International Thompson Publishing.

Hariyanti, W. Serta M. Nasir. 2002. Pengaruh Partisipasi Penyusunan Anggaran terhadap kinerja Manajerial : Peran Kecukupan Anggaran serta Komitmen Organisasi sebagai Variabel Intervenning. Simposium Nasional Akuntansi $V$,Semarang.

Indriantoro, N., serta B. Supomo. 1999. Metodologi Penelitian Bisnis untuk akuntansi serta Manajemen. Yogyakarta.: BPFE.

Milani, K. 1975. The Relationshipof Participation in Budget Setting to Industrial Supervisor Performance and Attitudes: A Field Study. The Accounting Review, April halaman 274284.

Mulyadi. 1997. Akuntansi Manajemen. Edisi dua. Yogyakarta: Bagian Penerbitan Sekolah Tinggi Ilmu Ekonomi YKPN.

Mulyasari, W. serta S. Sugiri. 2004.. Pengaruh Keadilan Persepsian, Komitmen pada Tujuan, serta Job Relevant Information terhadap Hubungan antara Partisipasi Anggaran serta kinerja Manajer. Simposium Nasional Akuntansi VII, Denpasar.

Poerwati, T. 2002. Pengaruh Partisipasi Penyusunan Anggaran terhadap kinerja Manajerial : Budaya Organisasi serta Motivasi sebagai Variabel Moderating. Simposium Nasional Akuntansi V, Semarang.

Pranesti, G serta Roekhudin. 2001. Analisis Korelasi Antara Gaya Kepemimpinan Dengan Penerapan Penganggaran Partisipasi. TEMA. Vol. II, No. 1. 
Puspaningsih, Abriyani. 2002. Pengaruh Partisipasi Dalam Penyusnan Anggaran terhadap Kepuasan Kerja serta kinerja Manajer. Jurnal akutansi serta auditing Indonesia (JAAI). Vol.6, No.2.

Rahman, F. A. 2002. Pengaruh Partisipasi Anggaran serta Keterlibatan Kerja terhadap Senjangan Anggaran dengan Komitmen Organisasi sebagai Variabel Moderating. Simposium Nasional Akuntansi $V$, Semarang.

Riyadi, S. 2000. Motivasi serta Pelimpahan Wewenang sebagai Variabel Moderating dalam Hubungan antara Partisipasi Penyusunan Anggaran serta kinerja Manajerial. Jurnal Riset akuntansi Indonesia. Vol.3, No.2.

Rosidi. 2000. Partisipasi dalam Penganggaran serta Prestasi Manajer : Pengaruh Komitmen Organisasi serta job relevant information. Jurnal Ekonomi serta Manajemen. Vol.1, No.1.

Sayekti, F., L. E. Wijayanti serta P. Iriana. 2002. Pengaruh Informasi Job Relevan serta Desentralisasi terhadap Hubungan antara Partisipasi dalam Penyusunan Anggaran dengan kinerja Manajerial. Simposium Nasional Akuntansi $V$, Semarang.

Sekaran, Uma. 1992. Research Methodes for Business. USA: John Wiley\& Sons, Inc.

Siegel, G serta H.R. Marconi. 1989. Behavioral Accounting. Ohio: South Western Publishing Co, Cincinnanti.
Supomo, B. serta Nur Indriantoro. 1998. Pengaruh Struktur serta Kultur Organisasi terhadap Kefektifan Partisipasi Anggaran dalam Peningkatan kinerja Manajerial : Studi Empiris Perusahaan Manufaktur. Kelola. No.18, 61-48.

Supriyono, R.A serta Syakhroza, A. 2003. Peran Asimetri Informasi Serta Peresponan Keinginan Sosial Sebagai Variabel Moderating Hubungan Antara Partsipasi Pengangaran Serta kinerja Manajer Di Indonesia.Simposium Nasional Akuntansi VI, Surabaya.

Supriyono, R.A. 2004. Pengaruh Komitmen Organisasi serta Keinginan Sosial terhadap Hubungan antara Partisipasi Anggaran serta kinerja Manajer. Jurnal Ekonomi serta Bisnis Indonesia. Vol.20, No.1

Terry, G.R, and L. Rue. 1991. DasarDasar Manajemen. Jakarta: Bumi Aksara. Wasisto, A serta Sholihin, M. 2004. Peran Partisipasi Penganggaran dalam Hubungan Antara Keadilan Prosedural Dengan kinerja Manajerial Serta Kepuasan Kerja. Simposium Nasional Akuntansi VII, Denpasar. 